\title{
Competence of newly qualified registered nurses from a nursing college
}

\author{
BG Morolong, MCur (Professional Nursing Science: Nursing Education) \\ University of Johannesburg
}

MM Chabeli, PhD

School of Nursing Science, University of Johannesburg

Keywords: comptence and newly qualified registered nurses.

\section{Correspondence address:}

Dr Mary Chabeli

University of Johannesburg

School of Nursing

PO Box 524

Auckland Park. 2006

South Africa

\section{Abstract: Curationis 28(2): $38-50$}

The South African education and training system, through its policy of outcomesbased education and training, has made competency a national priority. In compliance to this national requirement of producing competent learners, the South African Nursing Council ( $1999 \mathrm{~B}$ ) require that the beginner professional nurse practitioners and midwives have the necessary knowledge, skills, attitudes and values which will enable them to render efficient professional service.

The health care system also demands competent nurse practitioners to ensure quality in health care. In the light of competency being a national priority and a statutory demand, the research question that emerges is, how competent are the newly qualified registered nurses from a specific nursing college in clinical nursing education?

A quantitative, non-experimental contextual design was used to evaluate the competence of newly qualified registered nurses from a specific nursing college. The study was conducted in two phases. The first phase dealt with the development of an instrument together with its manual through the conceptualisation process. The second phase focused on the evaluation of the competency of newly qualified nurses using the instrument based on the steps of the nursing process. A pilot study was conducted to test the feasibility of the items of the instrument. During the evaluation phase, a sample of twenty-six newly qualified nurses was selected by simple random sampling from a target population of thirty-six newly qualified registered nurses. However, six participants withdrew from the study.

Data was collected in two general hospitals where the newly qualified registered nurses were working. Observation and questioning were used as data collection techniques in accordance with the developed instrument. Measures were taken to ensure internal validity and reliability of the results. To protect the rights of the participants, the researcher adhered to DENOSA'S (1998:2.2.1) ethical standards of research.

A descriptive statistical method of data analysis was used in this study. Findings revealed that newly qualified registered nurses were not competent. The highest score obtained was $51 \%$ and the lowest score was $22 \%$ with an average score of $34.05 \%$. The results concerning the implementation of the phases of the nursing process indicated that participants were fairly competent in terms of knowledge, skills, attitudes and values of assessment. Participants had very little knowledge of nursing diagnosis and were not competent on the skills of diagnosis. Participants lacked basic knowledge, skills, attitudes and values of the nursing process. They lacked critical thinking skills in their approach to providing quality patient care.

The recommendations of the study relate to improving the system of clinical accompaniment, reviewing the clinical facilities where learners are allocated, reviewing the implementation of the curriculum, the methods of teaching and the quality assurance mechanisms that are in place. Further research is recommended on competence of newly qualified registered nurses at other nursing colleges or similar context.

\section{Opsomming}

Die Suid-Afrikaanse onderwys- en opleidingsstelsel het, deur sy beleid van 
uitkomsgebaseerde onderwys en opleiding, bevoegheid ' $n$ nasionale prioriteit in onderwys en opleiding gemaak. Onderworpe aan die nasionale vereistes vir die daarstel van bevoegde leerders is die Suid-Afrikaanse Verpleegraad van mening dat die doel van ' $n$ kwalifikasie is om beginnerverpleegpraktisyns en -verloskundeverpleegkundiges, wat die nodige kennis, vaardighede, houding en waardes besit, toe te rus om ' $n$ professionele diens te verrig.

Die gesondheidsorgsisteem vereis bevoegde verpleegpraktisyns wat kwaliteit in die gesondheidsorg verseker. In die lig dat bekwaamheid "n nasionale prioriteit en ' $n$ statutêre vereiste is, is die navorsingsvraag in watter mate nuutgekwalifiseerde geregistreerde verpleegkundiges van ' $n$ spesifieke verpleegkollege bevoeg is in kliniese verpleging.

'n Kwantitatiewe, nie-eksperimentele kontekstuele ontwerp is gebruik om die bekwaamheid van nuutgekwalifiseerde geregistreerde verpleegkundiges van ' $n$ spesifieke verpleegkollege te evalueer.

' $n$ Loodsstudie is in die ontwikkelingsfase van die studie onderneem. 'n Instrument is ook gedurende hierdie fase ontwikkel. In die evalueringsfase is " $n$ monster van ses-en-twintig nuutgekwalifiseerde verpleegkundiges willekeurig geselekteer uit ' $n$ doelwitgroep van ses-en-dertig nuutgekwalifiseerde geregistreerde verpleegkundiges. Ses deelnemers het egter van die studie onttrek.

Data is by twee algemene hospitale ingesamel waar die nuutgekwalifiseerde geregistreerde verpleegkundiges werksaam was. ' $n$ Instrument is gebruik om data te versamel. Observasie en vraagstelling is as dataversamelingstegnieke gebruik. Stappe is geneem om interne geldigheid en betroubaarheid van die resultate te verseker. Om die regte van die deelnemers te beskerm, het navorser getrou gebly aan DENOSA (1998:2.2.1) se etiese standaarde van navorsing.

Beskrywende statistiek is gebruik om die numeriese data van die studie te analiseer. Daar is bevind dat nuut gekwalifiseerde verpleegkundiges nie bevoegd is nie. Die hoogste telling was $51 \%$ en die laagste $22 \%$ met $n$ gemiddeld van $34.05 \%$. Resultate met betrekking tot die implementering van die fases van die verpleegproses toon aan dat deelnemers redelik bevoegd is in terme van die volgende: kennis, vaardighede, houdings en waardes van beraming. Deelnemers het baie min kennis van verpleegdianose en is nie bevoegd in diagnoseringsvaardighede nie. Basiese kennis, vaardighede, houdings en waardes van die verpleegproses ontbreek, asook kritiese denkvaardighede in hulle benadering tot die voorsiening van gehaltepasientsorg.

Die aanbevelings van die studie hou verband met die verbetering van kliniese begeleiding, die hersiening van die kliniese fasiliteite waar die leerders geallokeer was, ' $n$ hersiening van die implementering van die kurrikulum, die onderrigmetodes en die beskikbare kwaliteitversekeringmeganismes. Verdere navorsing rakende bekwaamheid behoort gedoen te word by ander kolleges en in ' $n$ ander konteks.

\section{Introduction}

Quality nursing care is a constitutional right of both patients and clients, which must be upheld by competent nurses. It is unfortunate that this right is often violated by incompetent members of the nursing profession. This view is also held by Khoza and Ehlers (1998:69) who found that the newly qualified nurses appeared to be lacking in cognitive, affective and psychomotor competencies.

Mhlongo and Mashaba (1996:13) also found that as newly qualified nurses took up employment, controversy continued at the grass root level with regard to their competencies. As a result, some nursing service managers were reluctant to place newly qualified nurses in clinics immediately after graduating, as these nurses were expected to function more independently than in hospitals, where there was close supervision from more experienced nurses. To alleviate this problem. Gwele and Uys (1995:6) recommended that newly qualified registered nurses should undergo a six to twelve month internship. This recommendation has not yet been addressed in South Africa.

However, the providers of nursing education have the responsibility of producing nurses who are critical thinkers through the curriculum as determined by the SANC, the Education and Training Quality Assurance body for the nursing profession. Competency by using critical thinking skills to improve practice is an essential national priority and therefore knowledge and understanding of nursing student's critical thinking when on practice become important to nurse educators (ProfettoMcGrath 2003:569). At qualification level, learners should demonstrate ability to utilise critical thinking skills when implementing the scientific nursing process within their scope of practice in the provision of quality nursing care. It therefore became important that competence of newly qualified registered nurses from a specific nursing be evaluated.

\section{Research problem and research question}

The research studies conducted on the competence of newly qualified registered nurses revealed that they could not provide safe patient care (Khoza \& Ehlers, 1998:69; Mhlongo \& Mashaba. 1996: 13; Gwele \& Uys, 1995:6; Muller, 1998:4; Scheetz, 1989:29). In light of these research reports, the demands for competency by the higher education system and the health care system, the following research question was eminent: how competent are the newly qualified registered nurses from a specific nursing college in clinical practice using the nursing process?

\section{Purpose of the study}

The purpose of the study was to evaluate the competence of newly qualified registered nurses from a specific nursing college in clinical nursing practice, using the nursing process approach to provide quality nursing care.

\section{Objectives of the study}

The objectives of the study were to:

- develop an instrument and a manual through conceptualisation;

- evaluate the competence of newly qualified registered nurses in clinical nursing practice using the nursing process approach; and to

- describe recommendations based on the findings of the study on how to improve competency of newly qualified nurses.

\section{Theoretical framework}

The study departs from Muller's (1999) theoretical framework, though other theories supporting Muller's theory were also used, for example, the nursing 
Figure 1.1: Competence through the nursing process within the National and local context.

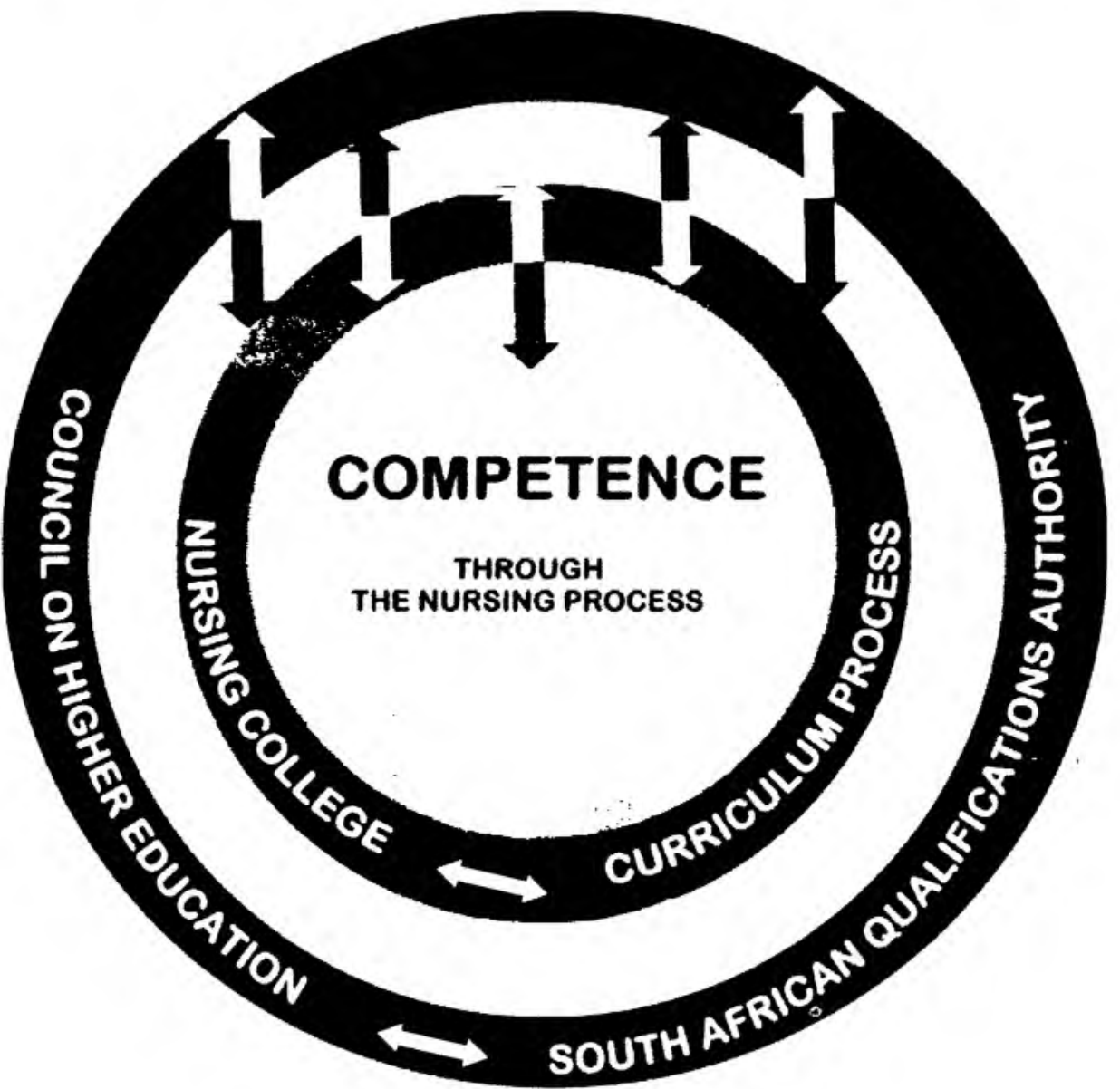

process as explained by Ellis and Nowlis (1994:131-192). Muller's theory served as a foundation for the development of the instrument used to evaluate competence of the newly qualified registered nurses.

\section{Definitions of central concepts}

- Competence refers to the application of the integration of knowledge, skills, attitudes and values in the context of nursing and midwifery practice (Muller, 1999). Competence embraces the notion of applied competence that suggests the integration of foundational, practical and reflexive competence (SAQA, 1998).

- A newly qualified registered nurse is a nurse who was educated and trained under the South African Nursing Council Regulation 425 of 22 February 1985 (as amended) and qualified as a nurse (general, psychiatric and community) and midwife/accoucheur. The nurse should have recently completed final examinations, i.e. a month before data collection.

- Clinical nursing practice is a dynamic constantly changing, real-life environment in which theoretical knowledge is integrated with practice (Chabeli, 2001:348).

- Curriculum process is the curriculum as experienced by the learner, and consists of learning strategies and assessment/evaluation methods (Quinn, 1995:297).

\section{Conceptualisation}

Conceptualisation of the key concepts of the study was done. This was done through clarification and defining of key concepts and integrating the research into the existing relevant theory (Mouton, 1998:109). The following key concepts were conceptualised for the purpose of developing the evaluation instrument: competency; the context within which clinical nursing practice occurs, influenced by the national legislation, local policies and the curriculum process.

\section{Competency}

Muller's theoretical framework was used to define and integrate the key concept of competence, which was clarified and conceptualised within the clinical nursing practice. Muller (1999) defines competence as the integration of knowledge, skills, attitudes and values within the context of nursing and midwifery practice.

This definition is in line with the SAQA definition of applied competence which refers to the overarching term for three interconnected kind of competence. The practical competence is the demonstrated ability in an authentic context to consider a range of possibilities for action, make considered decisions about which possibility to follow; and perform the chosen action. It is grounded in foundational competence where the learner demonstrates an understanding of the knowledge and thinking that underpins the action taken, and integrates it through reflexive competence. The learner, through reflexive competence, demonstrates the ability to integrate or connect performance and decision-making with understanding. The learner also demonstrates the ability to adapt to change and unforeseen circumstances 
and to explain the reasons behind these adaptations (Norms and Standards for Educators - Government Gazette No. 20844, February, 2000: 10; SAQA, 1998:4).

In this study, for consistency and congruency in conducting the research, patients suffering from congestive cardiac failure were selected as a common medical condition in the hospital to evaluate the competence of the newly qualified professional nurses using the nursing process.

According to Muller's theoretical framework, it is important that learners have knowledge of human biological sciences relating to relevant anatomy, physiology, patho-physiology, microbiology and parasitology; applied chemistry and physics; pharmacology; psychology; social sciences; education; management; related legislation; technology and nursing sciences. Details of the type of knowledge expected to be demonstrated are outlined in the manual (unpublished dissertation).

Muller (1999) is of the opinion that nurses should demonstrate the following skills: the psychomotor and affective skills, teaching and coaching skills, criticalreflective thinking skills, counselling, advocacy, good communication and interpersonal relationship skills, problem solving, accompaniment and management skills. Concerning attitudes and values, Muller (1999) is of the view that nurses should demonstrate a caring attitude, show compassion and commitment when nursing patients.

Quinn (1995:80) refers to attitude as an internal state that influences the choice of personal actions made by an individual. Ellis and Knowlis (1994:738) refer to values as "principles or standards of life that are highly priced", Nurses are expected to demonstrate values which show self-respect. empathy, reliability, honesty, justice and respect of patient's rights. The Batho-Pele principles in the White Paper (1997:16) should be upheld by nurses as these principles form the basis for any quality patient care. Muller (1998:238) further state that nurses should put a high premium on what to believe and do, why they do the activity, how to do it and attach compassion and commitment to what they do. She is also of the opinion that values form the basis of the nurse's perceptions or views on quality nursing.
The clinical evaluation instrument developed from the conceptualisation process included three parts. Part one (24 items) addressed the knowledge competence during the assessment phase, the knowledge of formulating the nursing diagnosis, the knowledge of how to plan for the identified diagnosis, the knowledge of how to implement the plan, the knowledge of how to evaluate the effect of the nursing intervention and the knowledge of the importance of record keeping. Part two (11 items) dealt with the skills of the six parts of the nursing process and part three ( 24 items) focused on the attitudes and values of nurses as they executed the six components of the nursing process. The manual gives detailed information expected from the participants under the sub-components of the three parts (unpublished dissertation). The evaluator had to acquaint herself/himself on the expectations from the manual before evaluating the student. Having a manual did not force the evaluator to focus strictly to the information, the knowledge and experience of the evaluator would add value to the evaluation activities. Since clinical evaluation is a complex exercise, two evaluators were used to improve the reliability of the participants' clinical performance (Ewan and White, 1984:216). The ratio scale ranged between 0 and 5, that is, 0 meant that the student is not competent. 1 meant that the student demonstrate very little competence. 2 represents fairly competent. 3 meant that the student is moderately competent. 4 meant that the competence of the student is good and 5 meant that the student demonstrated excellent competence using higher order thinking in the implementation of the nursing process of a patient with congestive cardiac failure.

\section{The context}

The higher education system within which the Council on Higher Education (CHE, 2002), the South African Qualification Authority (SAQA. 1995), the South African Nursing Council (SANC - R425 of 1985), the Higher Education Quality Committee (HEQC in the Higher Education Act no 101 of 1997) and the nursing college function. has an impact on the concept of competence to provide quality practice in the working world. This impact is depicted by the conceptual map in figure 1.1

The higher education and training system in South Africa is outcomes-based. The underlying principle of the higher education system is to produce a competent learner who can provide quality service in various working environments. According to the Higher Education Act (Act 101 of 1997:10), the Council on Higher Education, through its permanent committee, namely, the Higher Education Quality Committee (HEQC) and the Education and Training Quality Assurance body (ETQA) which, in this case, is the South African Nursing Council (SANC), are responsible for the promotion of quality assurance in higher education.

These structures are responsible to monitor quality education and training and to evaluate whether the objectives of higher education are being realised. The HEQC also audits the quality assurance mechanisms of institutions and accredit higher education programmes (CHE, 2002:3). The nursing college cannot be excluded. since it is affiliated to the university and is regarded as an institution of higher education, with similar expectations of producing competent nurses who will function independently in practice. The nursing college is functioning within the legal and professional boundaries of the country.

\section{The curriculum process}

The curriculum process of the college also impacts on the competence of learners. The curriculum of this specific nursing college is outcomes-based. This is in line with the demands of the education and training system of South Africa, as it moves from content-based to outcomes-based education and training. In developing the outcomesbased curriculum, the nursing college followed through the curriculum process by conducting a situational analysis. considering the critical cross-field outcomes as stated by SAQA (1995), identifying the learning area outcomes and the learning programme outcomes.

The learning outcomes determine the specific knowledge, skills, attitudes and values required by the learner. The curriculum goals were set, the assessment of the learning outcomes were made, the teaching and learning activities and resources were determined. Facilitative instructional strategies were determined. based on the learning outcomes and the assessment of the learning outcomes were done again to realise statement of learning outcomes which have not been 
achieved (Van der Horst \& McDonald, 1997:116).

Emphasis was on the development of the culture of teaching and learning based on the effective instructional and classroom management considering reflection, learner-oriented environment, rules, procedures, self-discipline, teacher and learner work ethics. Of the stated culture, reflection forms the basis on which effective teaching and learning can take place (Van der Horst \& McDonald, 1997:84,88).

\section{Research design and method}

A quantitative, non-experimental, contextual research design was used to evaluate the competence of newly qualified registered nurses trained at a specific nursing college (Polit \& Hungler, 1991:24,650). The research design was divided into two phases, the development phase and the evaluation phase. The purpose of the development phase was to develop the instrument and the manual through the process of conceptualisation. This instrument was used to evaluate the competence of newly qualified registered nurses. Recommendations were made.

\section{Population and sampling}

A target population of twenty-two newly qualified registered nurses were included in the pilot study to test and modify items of the instrument. Purposive sampling was done. The inclusion criteria used were that nurses should be from a specific nursing college and should be employed in general hospitals. The researcher was assisted by a fellow colleague who had background knowledge on quantitative research. The target population for the main study included all thirty-six newly qualified registered nurses from a specific nursing college. Simple random sampling was done to select twenty-six participants. However, six participants voluntarily withdrew from the study leaving the final sample at twenty.

\section{Data collection}

Observation and questioning were preferable data collection methods. For the main study, the researcher was assisted by an experienced expert clinical accompanist who was purposively selected for data collection. The researcher and the assistant used the developed instrument and its related manual, to evaluate the competence of newly qualified registered nurses.

Patients suffering from congestive cardiac failure, as the main medical diagnosis prevalent in the hospitals, where participants were employed, were carefully selected for the study. The newly qualified nurses were expected to demonstrate their competence using the nursing process approach to provide quality nursing care on the selected patients. Patients who were terminally ill were not selected for ethical reasons and also because it would be difficult to obtain subjective data from them. Consent to conduct the research was obtained from the selected patients.

Participants were expected to collect subjective and objective data, prioritise the health needs of the patient, formulate the nursing diagnosis, plan the nursing intervention and health promotion strategies, state how they would implement the plan, how they would evaluate and record the findings. Questions were asked in between to determine the depth of the participant's knowledge, skills and attitudes related to the condition.

Participants were given time to prepare the patients, read the patient's record to familiarise themselves with the condition, and prepare the equipments they would use to collect data. Each participant was scored against each and every competency item on the instrument by the researcher and the assistant independently. After evaluating each participant, a consensus score was reached by the two researchers. Data collection from each participant took approximately 45 to 60 minutes per participant.

The duration of the entire data collection was two and a half days with breaks in between for tea and lunch. Only twenty participants could be evaluated. The last six participants expressed the view that they did not feel competent enough to subject themselves to such evaluation. They requested to withdraw from participating in the research. The request was respected and appreciated by the researcher since they were acting within their rights.

\section{Data analysis}

Data from the pilot study was analysed manually by the researcher using percentages. Data analysis for the evaluation phase was done by a statistical consultant. The descriptive analysis of data employed measures such as percentages, bar graphs, tables, boxand-whisker plots. The box-and-whisker plots as indicated in figures 1.31 .4 and 1.5 shows the characteristics of the data such as the median, outliers, minimum and maximum scores.

The median is indicated by a thick black vertical line. Burns and Grove (1993:475) refer to the median as the score at the exact centre of the ungrouped frequency distribution obtained by rank ordering the scores. The outliers are shown as black thick dots which indicate extreme scores obtained. Burns and Grove (1993:476) refer to outliers as subjects with extreme scores that are widely separated from the scores of the rest of the subjects.

The minimum and maximum scores are indicated by thin black vertical lines on either side of the box. Figure 1.2 is a bar graph indicating the percentage distribution of participants in the evaluation phase. Table 1.2 to 1.7 shows the minimum, maximum, mean and standard deviation of the scores obtained by participants. Burns and Grove (1993:772) refer to the mean as the value obtained by summing up all the scores and dividing that total by the number of scores being summed. The standard deviation indicates how values vary about the mean of the distribution (Brink, 1996:186). The larger the standard deviation, the more spread out the scores are about the mean in a distribution.

\section{Ethical considerations}

To protect the rights of the participants, the researcher adhered to DENOSA (1998:2.2.1)'s ethical standards of research. The study was also approved by the research ethics committee of a university. Informed consent was obtained from the Department of Health, hospital authorities and participants. Anonymity, privacy, fair treatment, protection from harm and discomfort were ascertained.

\section{Measures to ensure validity}

To ensure content validity, the constructs measured were derived from literature and Muller (1999) theoretical framework on 
competence of a professional nurse using the nursing process components. A fivepoint scale instrument with 59 items was developed. The items on the instrument provided an adequate sample representative of the concept competence using the nursing process.

\section{Measures to ensure reliability}

A pilot study was done to test and correct the items on the instrument and to assess the feasibility of the study. Simple random sampling was done to ensure that the sample was representative of the target population. A briefing session on the purpose and objectives of the research was done. The assistant of the researcher was purposively selected because of her extensive ICU experience and clinical accompaniment of student nurses. Both the researcher and the assistant used the same instrument to evaluate the competence of the participants. Scoring was done independently during the evaluation process and a consensus score was reached by both researchers.

\section{Research findings}

The research findings are presented in the form of 7 tables, the 3 box-andwhisker plots and 1 figure.

According to the findings of the pilot study, all six participants who were employed within the first six months after completing the course, ranged from fair to good competence.

However, the findings of the main study revealed that, of the twenty participants who participated in the research, only one participant scored $51 \%$, which was the highest score. The lowest score obtained by one participant was $22 \%$. The average score was $34.05 \%$. See table 1.1.

Figure 1.2 indicates the mode of $32-36 \%$ occurring seven times in the data set.

Table 1.2 indicate the scores obtained by participants on assessment. The participants were found to be fairly competent in the knowledge, skills, attitude and values of phase.

Table 1.1 Percentages obtained by participants in the evaluation phase.

\begin{tabular}{|l|l|l|l|}
\hline $\begin{array}{l}\text { Participant's } \\
\text { code numbers }\end{array}$ & percentages & $\begin{array}{l}\text { participant's } \\
\text { code numbers }\end{array}$ & percentages \\
\hline 01 & $37 \%$ & 11 & $28 \%$ \\
\hline 02 & $32 \%$ & 12 & $34 \%$ \\
\hline 03 & $33 \%$ & 13 & $33 \%$ \\
\hline 04 & $35 \%$ & 14 & $22 \%$ \\
\hline 05 & $39 \%$ & 15 & $26 \%$ \\
\hline 06 & $31 \%$ & 16 & $26 \%$ \\
\hline 07 & $34 \%$ & 17 & $25 \%$ \\
\hline 08 & $51 \%$ & 18 & $29 \%$ \\
\hline 09 & $35 \%$ & 19 & $24 \%$ \\
\hline 10 & $37 \%$ & 20 & $30 \%$ \\
\hline
\end{tabular}

Average Score $=34.05 \%$

assessment of patients. Table 1.3 showed that participants were found to be very little competent in the knowledge of diagnosis and not competent in the skills of diagnosis.

Table 1.4 indicates the scores obtained by participants on planning. The newly qualified nurses showed very little competence in the knowledge of planning, but were fairly competent in the skills of planning. Table 1.5 indicate the scores obtained by participants on implementation. The study revealed that newly qualified nurses were fairly competent in terms of knowledge of implementation, but very little competent in the skills of implementation.

Table 1.6 indicate the scores obtained by participants on evaluation. The findings of the study showed that nurses were fairly competent in the knowledge of evaluation, but not competent in the skills

Figure 1.2 A bar graph: percentage distribution of participants in the evaluation

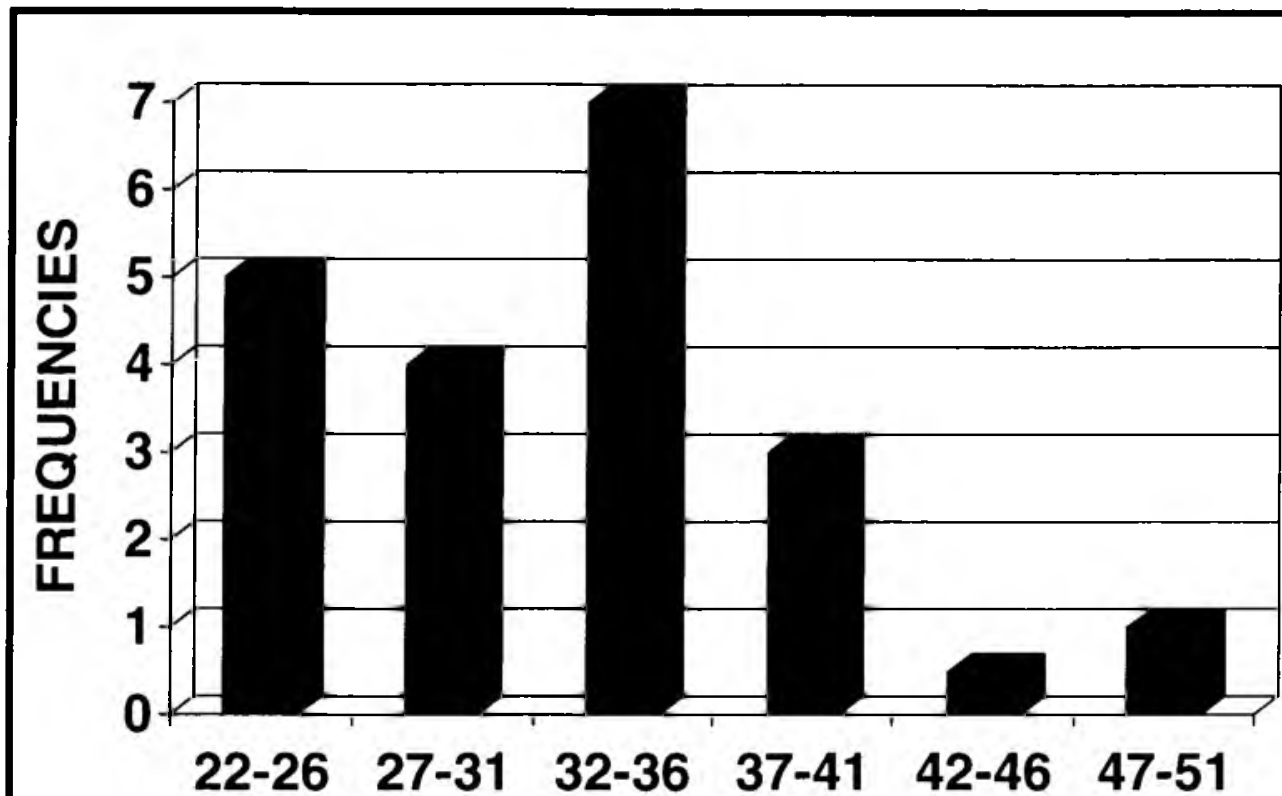

DERCENTAGES 


\begin{tabular}{|c|c|c|c|c|}
\hline 1.KNOWLEDGE & $\begin{array}{l}\text { Minimum } \\
\text { score }\end{array}$ & $\begin{array}{l}\text { maximum } \\
\text { score }\end{array}$ & $\begin{array}{l}\text { mean } \\
\text { score }\end{array}$ & $\begin{array}{l}\text { standard } \\
\text { deviation }\end{array}$ \\
\hline $\begin{array}{l}\text { 1.1The nurse demonstrates knowledge of: } \\
\text { 1.1.1 Complete } \backslash \text { holistic assessment of congestive } \\
\text { cardiac failure patient. }\end{array}$ & 1.00 & 3.00 & 1.8500 & 0.4894 \\
\hline 1.1.2Importance of team work in assessing patients. & 1.00 & 3.00 & 1.8000 & 0.6156 \\
\hline 1.1.3 Relevant data to congestive cardiac failure. & 1.00 & 3.00 & 1.7000 & 0.5712 \\
\hline 1.1.4 Data that is valid and reliable & 1.00 & 3.00 & 1.7000 & 0.5712 \\
\hline Average & 1.00 & 3.00 & 1.7000 & 0.5712 \\
\hline \multicolumn{5}{|l|}{ 2. SKILLS } \\
\hline $\begin{array}{l}\text { 2.1 The nurse demonstrate the skill of: } \\
\text { 2.1.1 Interviewing patients. }\end{array}$ & 0.00 & 3.00 & 1.2500 & 0.6387 \\
\hline 2.1.2Observation & 1.00 & 4.00 & 1.7000 & 0.9234 \\
\hline 2.1.4Physical examination & 1.00 & 3.00 & 1.6000 & 0.7539 \\
\hline Average & 1.00 & 3.00 & 1.5167 & 0.6067 \\
\hline \multicolumn{5}{|l|}{ 3. ATTITUDFS AND VALUES } \\
\hline $\begin{array}{l}\text { 3.1 The nurse demonstrates attitudes and values } \\
\text { that show: } \\
\text { 3.1.1 Respect for human rights }\end{array}$ & 1.00 & 4.00 & 2.5500 & 1.0990 \\
\hline 3.1.2 Empathy and care & 0.00 & 4.00 & 2.5500 & 1.2680 \\
\hline 3.1.3Assertiveness & 1.00 & 4.00 & 1.7000 & 0.8013 \\
\hline 3.1.4Confidence & 1.00 & 4.00 & 1.7000 & 0.8013 \\
\hline Average & 0.75 & 3.50 & 1.7750 & 0.6925 \\
\hline
\end{tabular}

of evaluation. Table 1.7 indicate scores obtained by participants on recording. The newly qualified nurses were found to be moderately competent in the knowledge and skills of recording. These results are further depicted in the boxand-whisker plots on figures $1.3,1.4$ and 1.5 .

\section{Discussion of findings}

The findings of the study revealed that the newly qualified nurses from a specific nursing college were not competent with regard to the management of a patient suffering from congestive cardiac failure using the nursing process as indicated by only one student obtaining $51 \%$ and the average performance of $34.05 \%$.
Participants were found to be very little competent in the knowledge of diagnosis, planning and the skills of implementation. They were fairly competent in the knowledge of assessment, implementation and evaluation, as well as being fairly competent in the skills of assessment and planning. Their knowledge and skills of recording was found to be moderately competent.

The implications of these findings were that the newly qualified nurses from a specific college were unable to apply the nursing process when caring for patients with congestive cardiac failure, a common condition found in the hospitals. These findings are supported by previous studies of nursing students on clinical competence conducted by Lofmark, Hannersjo and Wikblad (1999:946). The study revealed that students showed uncertainty in their knowledge of assessment of patient's needs, as they either under-estimated or over-estimated patient's needs and problems during assessment.

The findings revealed that the newly qualified nurses were fairly competent in the assessment of patients. This could imply that the participants lacked the knowledge of integrating basic nursing science, human biological sciences, chemical sciences, pharmacology and social sciences. During the assessment phase, it is important that the student 


\begin{tabular}{|c|c|c|c|c|}
\hline 1.KNOWLEDGE & $\begin{array}{l}\text { Minimum } \\
\text { score }\end{array}$ & $\begin{array}{l}\text { maximun } \\
\text { score }\end{array}$ & $\begin{array}{l}\text { mean } \\
\text { score }\end{array}$ & $\begin{array}{l}\text { standard } \\
\text { deviation }\end{array}$ \\
\hline $\begin{array}{l}\text { 1.1 The nurse demonstrates knowledge of: } \\
\text { 1.1.1Formulation of a comprehensive or complete } \\
\text { nursing diagnosis }\end{array}$ & 0.00 & 4.00 & 0.2500 & 0.9105 \\
\hline 1.1.2Data that support the diagnosis & 0.00 & 4.00 & 1.1500 & 0.7452 \\
\hline $\begin{array}{l}\text { 1.1.3Data that justifies the diagnosis related to the } \\
\text { pathophysiology }\end{array}$ & 0.00 & 3.00 & 1.1000 & 0.5525 \\
\hline Average & 0.00 & 3.67 & 0.8333 & 0.7050 \\
\hline \multicolumn{5}{|l|}{ 2.SKILLS } \\
\hline $\begin{array}{l}\text { 2.1 The nurse demonstrates skills of: } \\
\text { 2.1.1Critical thinking }\end{array}$ & 0.00 & 0.00 & 0.0000 & 0.0000 \\
\hline Average & 0.00 & 0.00 & 0.0000 & 0.0000 \\
\hline
\end{tabular}

collect critical information and identify the important cues about the patient and explain why the information is critical, significant or insignificant to a specific patient (Oermann 1998:327).

The withdrawal of six participants who indicated that they were not competent in executing nursing process, since their knowledge of pathophysiology was lacking, was also evidential. This poses a serious implication to the care and safety of the patient if the products of a basic nursing programme are incompetent in their practice. The underlying problem is the inability to use critical thinking in the care of the patient. This was demonstrated by student during the assessment and planning phase when they were unable to justify the reasons for making particular decisions, that is, the data on which they based their clinical judgment and the assumptions they made about the patient. Oermann (1998:323) state that when students make clinical judgment, they must consider other possible views of the clinical situation, provide reasons behind the actions they took. Expert clinical reasoning depends heavily on relevant knowledge base and strongly connected to the use of critical thinking (Paul 1993:473).

The evaluator has the responsibility of asking open-ended questions such as why, what if, and what else is possible to assess the critical thinking of students.
Oermann (1998:323), in the same vein, is of the opinion that one way to develop these questions is within the broad framework of the nursing process.

The findings also demonstrate a theorypractice gap. Ineffective clinical accompaniment of students by nurse educators and professional nurses, also contributes to lack of clinical competence of students. Effective clinical accompaniment facilitates critical thinking of students. Critical thinking is an important cognitive skill for nurses to develop in order to be able to weigh multiple possibilities and to arrive at informed clinical decisions for improved nursing care of patients (Oermann, 1998:322).

The findings of the study revealed that the newly qualified nurses were very little competent in the skills of implementation. This causes concern to the researcher, because nursing is basically a practical skill. According to Reilly and Oermann (1985:1), nursing is a hands-on profession which draws its satisfaction from the clinical practice setting, where specialised skills and the acceptance of a patient as an autonomous being must be the norm.

Clinical nursing education, according to Chabeli (2001:150) is a dynamic, multipurpose environment in which the theoretical component is integrated into practice. It provides the learner with a meaningful, authentic and humane experience. Chabeli further states that, the teacher, as a facilitator should create the environment that will promote the integration of knowledge, skills attitudes and values in order for students to be able to render holistic and comprehensive nursing care to patients using the nursing process as a vehicle. The findings of the study revealed that, newly qualified nurses from a specific nursing college were unable to use the nursing process, as a vehicle to render holistic and comprehensive care to patients suffering from a congestive cardiac failure.

The implications of the findings were that nurse educators at this specific nursing college need to review their teaching and assessment methods. Dialectical and dialogical teaching and assessment methods that will stimulate critical thinking of students should be used (Gravett, 2001:35; Brookfield, 1987:13; Paul, 1993:333).

The nursing process has been criticised, as being mechanistic, deductive, reductionistic, method-centred, diseasecentred and following the medical model approach (Lindsey \& Hartrick 1996: 108). However, the researcher is of the opinion that if nurses from this college knew how to apply the nursing process effectively to facilitate critical thinking, they would have been in a better position to apply the nursing process on a patient suffering from congestive cardiac failure in a 


\begin{tabular}{|c|c|c|c|c|}
\hline 1.KNOWLEDGE & $\begin{array}{l}\text { Minimum } \\
\text { score }\end{array}$ & $\begin{array}{l}\text { Maximum } \\
\text { score }\end{array}$ & $\begin{array}{l}\text { Mean } \\
\text { score }\end{array}$ & $\begin{array}{l}\text { Standard } \\
\text { deviation }\end{array}$ \\
\hline $\begin{array}{l}\text { 1.1 The nurse demonstrates knowledge of: } \\
\text { 1.1.1 Desired outcomes } \text { goals }\end{array}$ & 0.00 & 2.00 & 0.2000 & 0.5231 \\
\hline $\begin{array}{l}\text { 1.1.2 Logical prioritisation of health needs and } \\
\text { problems of patients. }\end{array}$ & 1.00 & 3.00 & 2.0000 & 0.7255 \\
\hline $\begin{array}{l}\text { 1.1.3 Specific nursing actions related to congestive } \\
\text { cardiac failure }\end{array}$ & 1.00 & 3.00 & 2.1000 & 0.6407 \\
\hline $\begin{array}{l}\text { 1.1.4 Specific equipment required during nursing } \\
\text { intervention }\end{array}$ & 1.00 & 3.00 & 1.4500 & 0.8256 \\
\hline 1.1.5 Mobilisation of human and material resources & 0.00 & 2.00 & 0.5500 & 0.6863 \\
\hline 1.1.6 Appropriate referral system & 0.00 & 4.00 & 1.0500 & 1.1910 \\
\hline Average & 0.33 & 2.50 & 1.2250 & 0.5361 \\
\hline \multicolumn{5}{|l|}{ 2. Skills } \\
\hline $\begin{array}{l}\text { 2.1 The nurse demonstrates skills of: } \\
\text { 2.1.1 Drawing up the nursing plan }\end{array}$ & 1.00 & 2.00 & 1.7778 & 0.4278 \\
\hline Average & 1.00 & 2.00 & 1.7778 & 0.4278 \\
\hline
\end{tabular}

holistic manner.

\section{Study limitations}

The contextual nature of the study and the participation of 20 participants only, makes the findings not to be generalised to other nursing colleges. The pilot study population (six participants), although from the same college, differed from the evaluation group in terms of working experience. The pilot study participants had six month working experience, whilst the participants of the main study had one month working experience, as they had just completed the programme.

The participants equated their participation in the research with the objective simulated clinical evaluation examination (OSCE) which was intimidating and brought about tension and stress on students while they were student nurses. This situation could have had a negative influence on the performance of the participants. The withdrawal of the six participants who were last on the list. on receiving the feedback from the participants who were finished with the research, stated that they are afraid to be subjected to the same (OSCE) as they did whilst they were students. The situation brought fear to them and the researcher regarded that as a limitation to the study.

\section{Recommendations}

In view of the findings of the study, the following recommendations are made:

\section{- $\quad$ Nursing practice}

The system of accompaniment of learners to clinical areas should be reviewed. It is through effective clinical accompaniment of learners that theory and practice can be correlated, and the problems encountered by learners can be identified early and addressed.

The clinical facilities where learners are allocated should also be reviewed for availability and accessibility of human, material and other resources necessary for the facilitation of learning. All human beings learn by and through experience and therefore, availability of resources in the clinical area can help to enhance experiential learning.

To improve the level of competence in nursing practice, educators should be reflective and critical thinkers themselves in order to be able to facilitate critical thinking of students (Mangena 2003:35). They should formulate ill-structured clinical scenarios, hold clinical conferences and engage in problembased learning approach to encourage the students' inquiry mind using the available resources. They should strive at closing the theory-practice gap (Rolfe, 1996:1).

\section{- Nursing education}

The college should review the implementation of its curriculum in order to identify reasons as to why clinical learning outcomes were not achieved. The system of evaluation/assessment, methods of teaching and the quality assurance systems of the college should also be reviewed. Multi-modal methods of teaching and assessment to facilitate critical thinking and problem-solving skills should be considered at the college.

Critical thinking enables the learners to analyse, synthesise and evaluate information independently. Quality assurance mechanisms such as peer group evaluation, staff development programmes and monitoring of college standards of education and training by the university which the college is 


\begin{tabular}{|c|c|c|c|c|}
\hline 1.KNOWLEDGE & $\begin{array}{l}\text { Minimum } \\
\text { score }\end{array}$ & $\begin{array}{l}\text { Maximum } \\
\text { score }\end{array}$ & $\begin{array}{l}\text { Mean } \\
\text { score }\end{array}$ & $\begin{array}{l}\text { Standard } \\
\text { deviation }\end{array}$ \\
\hline $\begin{array}{l}\text { 1.1 The nurse demonstrates knowledge of: } \\
\text { 1.1.1Comprehensivelholistic nursing care }\end{array}$ & 1.00 & 3.00 & 1.8500 & 0.4894 \\
\hline 1.1.2 Drugs related to congestive cardiac failure & 1.00 & 3.00 & 1.5500 & 0.6048 \\
\hline 1.1.3Safe administration of medication & 1.00 & 3.00 & 2.7500 & 0.5501 \\
\hline 1.1.4 Maintenance of a safe environment & 2.00 & 4.00 & 2.9500 & 0.3940 \\
\hline 1.1.5Health promotion & 0.00 & 2.00 & 0.8500 & 0.6708 \\
\hline $\begin{array}{l}\text { 1.1.6 Importance of team work in the implementation of } \\
\text { nursing care plan }\end{array}$ & 1.00 & 3.00 & 1.9000 & 0.6407 \\
\hline 1.1.7 Aspects related to scope of practice( R2598) & 0.00 & 3.00 & 0.9500 & 0.8256 \\
\hline $\begin{array}{l}\text { 1.1.8 Aspects related to the regulation on acts and } \\
\text { omissions ( } \mathrm{R} 387 \text { ) }\end{array}$ & 0.00 & 3.00 & 0.3000 & 0.7327 \\
\hline Average & 1.33 & 3.67 & 2.1833 & 0.4953 \\
\hline \multicolumn{5}{|l|}{ 2.SKILLS } \\
\hline $\begin{array}{l}\text { 2.1 The nurse demonstrates skills of: } \\
\text { 2.1.1 Clinical care of patients }\end{array}$ & 1.00 & 3.00 & 1.9000 & 0.5525 \\
\hline 2.1.2 Counselling and educating the patient & 0.00 & 1.00 & 0.4000 & 0.5026 \\
\hline Average & 0.50 & 2.00 & 1.1500 & 0.4323 \\
\hline
\end{tabular}

affiliated to, should also be in place.

The college library should easily be accessible to learners and educators, and should have the most recent relevant reading material. Information technology support facilities should be made available in the library for students to gain access to the internet to facilitate learning. The assessment of learners should not only focus on the ability of the students to recall and comprehend facts, but also on their ability to interpret, analyse, synthesise, make inferences and to evaluate information.

\section{Research}

Further research on the competence of newly qualified registered nurses at other nursing colleges using a more representative sample is recommended. The instrument should undergo further usage and refinement so as to claim construct validity.

\section{Conclusions}

The findings of the study are supported by previous studies on competency of newly qualified registered nurses. The findings of the study as indicated by only one student obtaining $51 \%$ and regarded as competent, and the mean average performance of $34.05 \%$ indicate that newly qualified nurses participants lack adequate knowledge of assessment, diagnosis, planning, implementation, evaluation and recording of the selected patient's needs. The findings imply that these nurses were unable to render quality care to patients suffering from congestive cardiac failure. Findings and the literature supporting the results also suggest, however, that nurses need to continue to be developed in these areas of nursing care.

However, the research findings are confined to a specific nursing college and can not be generalised to other colleges, provincially or nationally. Further research could be done to establish whether newly qualified nurses from other colleges experience similar problems. Nurse educators and the clinical practitioners have a responsibility to revisit their teaching and assessment method to facilitate critical thinking of students in clinical nursing education. Critical thinking and reflective learning is the educational learning outcome of all educational programmes nationally and internationally.

\section{Reference}

BRINK, H 1996: Fundamentals of research methodology for health care Professionals. Kenwyn: Juta \& Co.

BROOKFIELD, S 1987: Developing critical thinkers. Open University: Milton Keynes.

BURNS, N \& GROVE, SK 1993: The practice of nursing research; second edition. Philadelphia: JB Lippincott. 
Table 1.6: Scores obtained by participants on evaluation

\begin{tabular}{|l|l|l|l|c|}
\hline 1.KNOWIFDGE & $\begin{array}{l}\text { Mlinimum } \\
\text { score }\end{array}$ & $\begin{array}{l}\text { Maximum } \\
\text { score }\end{array}$ & $\begin{array}{l}\text { Mean } \\
\text { score }\end{array}$ & $\begin{array}{l}\text { Standard } \\
\text { deviation }\end{array}$ \\
\hline $\begin{array}{l}\text { 1.1 The nurse demonstrates knowledge of: } \\
\text { 1.1.1 The standards and evaluation of quality } \\
\text { nursing care }\end{array}$ & 0.00 & 3.00 & 2.1500 & 0.6708 \\
\hline Average & 0.00 & 3.00 & 2.1500 & 0.6708 \\
\hline 2SKILLS & & & & \\
\hline $\begin{array}{l}\text { 2.1 The nurse demonstrates skills of: } \\
\text { 2.1.1 Conducting a nursing audit }\end{array}$ & 0.00 & 2.00 & 0.3500 & 0.5871 \\
\hline Average & 0.00 & 2.00 & 0.3500 & 0.5871 \\
\hline
\end{tabular}

Table 1.7 Scores obtained by participants on recording

\begin{tabular}{|l|l|l|l|l|}
\hline 1.KNOWLEDGE & $\begin{array}{l}\text { Minimum } \\
\text { score }\end{array}$ & $\begin{array}{l}\text { Maximum } \\
\text { score }\end{array}$ & $\begin{array}{l}\text { Mean } \\
\text { score }\end{array}$ & $\begin{array}{l}\text { Standard } \\
\text { deviation }\end{array}$ \\
\hline $\begin{array}{l}\text { 1.IThe nurse demonstrates } \\
\text { knowledge of : } \\
\text { 1.1.1Complete and accurate recording of patient's } \\
\text { information. }\end{array}$ & 2.00 & 3.00 & 2.6500 & 0.4894 \\
\hline 1.1.2The purpose of record keeping and recording. & 2.00 & 3.00 & 2.6500 & 0.4894 \\
\hline Average & 2.00 & 3.00 & 2.6500 & 0.4894 \\
\hline 2.SKILLS & & & & \\
\hline $\begin{array}{l}\text { 2.1The nurse demonstrates skills of: } \\
\text { 2.1.1Communication and interpersonal relationship. }\end{array}$ & 1.00 & 4.00 & 2.8500 & 0.5871 \\
\hline 2.1.2 Writing skills & 2.00 & 3.00 & 2.9000 & 0.3078 \\
\hline 2.1.3 Management and maintenance of records & 2.00 & 3.00 & 2.6500 & 0.4894 \\
\hline Average & 2.00 & 3.33 & 2.8000 & 0.3651 \\
\hline
\end{tabular}

CHABELI, MM 2001: A model to facilitate reflective thinking in clinical nursing education. (DCur Thesis unpublished) Johannesburg: Rand Afrikaans University.

\section{COUNCIL ON HIGHER EDUCATION}

(South Africa). Programme accreditation framework 2002. Pretoria: Council on Higher Education.

DEMOCRATIC NURSES ORGANISATION OF SOUTH AFRICA (South Africa). DENOSA position statements 1998.
ELLIS, JR \& NOWLIS, EA 1994: Nursing a humanistic needs approach; fifth edition. Philadelphia: JB Lippincott.

EWAN, C \& WHITE, R 1984: Teaching nursing: A self-instruction handbook. London: Croom Helm.

GRAVETT, S 2001: Adult learning: Designing and implementing learning events - a dialogic approach. Pretoria: Van Schaik Publishers.

GWELE, NS \& UYS, L 1995: Views of leading nurse educators regarding the comprehensive basic nursing programme. Curationis. 18(1) March. 1995:6.

KHOZA, LB \& EHLERS, VJ 1998: The competence of newly qualified nurses as viewed by senior professional nurses. Curationis. Sept. 1998.

LINDSEY, E \& HARTRICK, G 1996 : Health - promoting nursing practice : the Demise of the nursing process? Journal of Advanced Nursing. 23, $106-112$.

LOFMARK, A; HANNERSJO, S \& 
Figure 1.3 The box-and-whisker plots of knowledge of assessment, diagnosis, planning, implementation, evaluation and recording

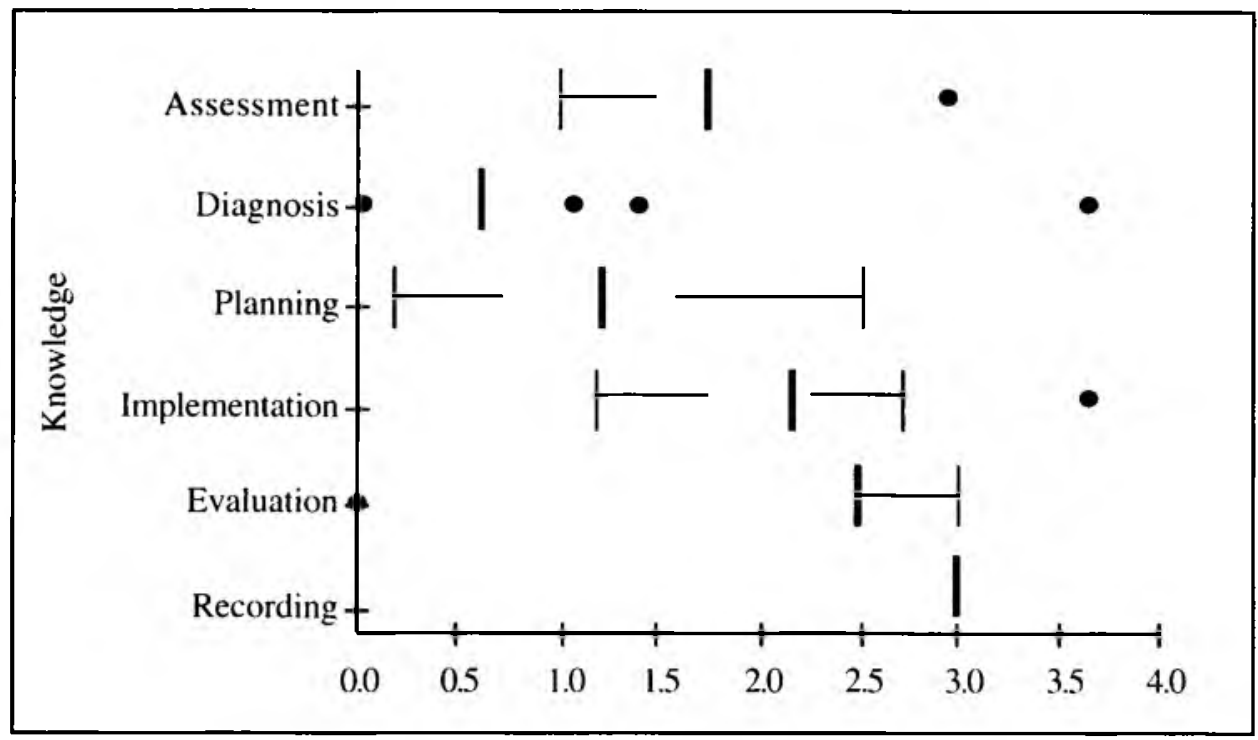

Figure 1.4 The box-and-whisker plots of skills of assessment, diagnosis, planning, implementation, evaluation and recording

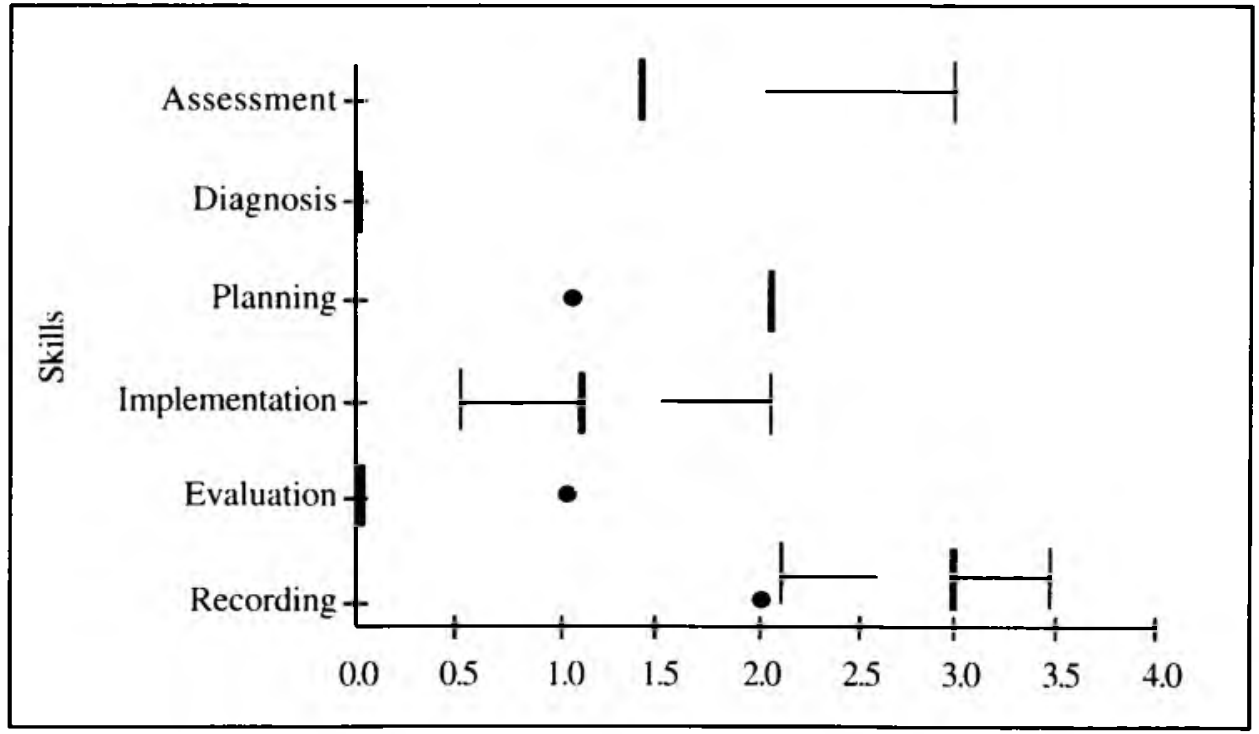

Figure 1.5 The box-and-whisker plots on knowledge of attitudes and values of assessment

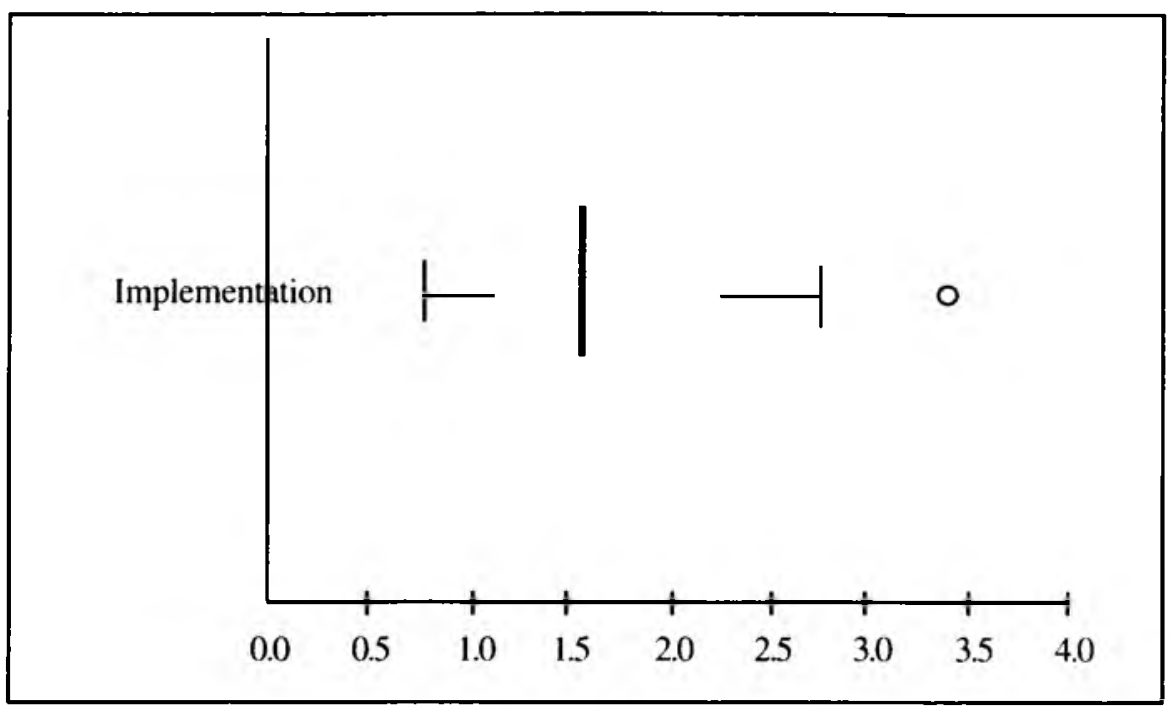

WIKBLAD, K 1999: A summative evaluation of Clinical competence students' and nurses' perception of in-patients' Individual physical and emotional needs. Journal of Advanced Nursing. 29 (4) April, 1999:946.

MANGENA, A \& CHABELI, MM 2005: Strategies to overcome obstacles in the facilitation of critical thinking in nursing education. Nurse Education Today. 25(4) May 2005: 291298.

MHLONGO, CS \& MASHABA,TG 1996: A study of clinical performance of nurses who recently completed the comprehensive basic nursing course. Curationis. 19(4) Dec. 1996:13

MOUTON, J 1998: Understanding social research; second impression. Pretoria: Van Schaik.

MULLER, ME 1999: (South Africa). Nursing/Midwifery practice standards Pretoria: South African Nursing Council.

MULLER, ME 1998: Nursing dynamics; second edition. Sandton: Heinneman.

OERMANN, M 1998: How to assess critical thinking in clinical practice. Dimensions of critical care nursing. 17 (6): $322-327$.

PAUL, R 1993: Critical thinking: What every person needs to survive in a rapidly changing world. Foundation for critical thinking, Santa Rosa.

POLIT, DF \& HUNGLER, BP 1991: Nursing research principles and methods; Fourth edition. Philadelphia: JB Lippincott.

PROFETTO-McGRATH. J 2003: The relationship of critical thinking skills and the critical thinking dispositions of baccalaureate nursing students. Journal of Advanced Nursing. 43(6). 569-577.

QUINN, FM 1995: The principles and practice of nurse education. London: Chapman-Hall.

RFILLY,DE \& OERMAN, MIH 1985: The clinical field: its use in nursing education. Norwalk: Appleton and Lange.

ROLFE, G 1996: Closing the theory- 
SCHEETZ, LJ 1989: Baccalaureate nursing students' perception on programme and development of clinical competence. Journal of nursing education. 28 ( 1) Jan. 1989: 29.

SOUTH AFRICA (Republic). The White Paper on transforming Public Service delivery 1997: Batho-Pele: Pretoria: Government Printers.

SOUTH AFRICA (South Africa) The Higher Education Act ( Act 101 of 1997) Pretoria: Government Printers.

SOUTH AFRICA (Republic). South African Qualifications Authority, 1998: Bulletin. Pretoria: Government Printers.

SOUTH AFRICA (Republic). South African Qualifications Authority Act (Act no 58 Of 1995), Pretoria: Government Printers.

SOUTH AFRICAN NURSING COUNCIL (South Africa). Requirements and guidelines for the transformation of education and training of learners in the basic programme leading to registration as a nurse (general, psychiatry and community) and midwife/accoucher 1999 : Discussion document B. Pretoria: South African Nursing Council.

SOUTH AFRICAN NURSING COUNCIL (South Africa). Regulation relating to acts and omission 1985. R387. Pretoria: SANC.

SOUTH AFRICAN NURSING COUNCIL (South Africa). Regulation relating to the scope of practice 1985 . R2598. Pretoria: SANC.

\section{SOUTH AFRICAN NURSING} COUNCIL (South Africa). Regulation relating to the approval of the minimum requirements for the education and training of a nurse (general, psychiatry and community ) and midwifel accoucher 1985 R425 Pretoria: SANC.

VAN DER HORST, H \& MCDONALD, R 1997: Outcomes -Based Education. A teacher's manual. Pretoria: Kagiso Publishers. 